Jurnal Pendidikan dan Pemberdayaan Masyarakat
Volume 3 - Nomor 1, Maret 2016, (48 - 59)

\title{
PENGEMBANGAN MEDIA PEMBELAJARAN BIG BOOK UNTUK PEMBENTUKAN KARAKTER ANAK USIA DINI
}

\author{
Ivonne Hafidlatil Kiromi ${ }^{1)}$, Puji Yanti Fauziah ${ }^{2)}$ \\ ${ }^{1}$ Jl Hayam Wuruk II/2 No.44 Mangunharjo, Probolinggo. Email: kim367511@gmail.com \\ ${ }^{2}$ Prodi Pendidikan Luar Sekolah, Program Pascasarjana, Universitas Negeri Yogyakarta, \\ Jl. Colombo No. 1, Karangmalang, Yogyakarta 55281, Indonesia. Email: pujiyanti@uny.ac.id
}

\begin{abstract}
Abstrak
Penelitian ini bertujuan untuk membantu guru dalam mengembangkan media pembelajaran khususnya media pembelajaran dalam pembentukan karakter anak usia dini di PAUD Bakti Baitussalam Bantul. Penelitian ini menggunakan metode Research $\mathcal{E}$ Development (R\&D). Media pembelajaran yang dihasilkan berupa media pembelajaran big book. Data diperoleh melalui teknik wawancara, lembar penilaian dari ahli media dan materi. Subjek penelitian ini adalah anak kelompok bermain yang berjumlah 28 anak. Berdasarkan hasil analisis data dan pembahasan dapat disimpulkan bahwa media pembelajran big book dapat membantu guru dalam mengembangkan media pembelajaran, khususnya pengembangan untuk pembentukan karakter anak usia dini. Penggunaan big book berdampak positive terhadap pembentukan karakter anak, dengan rata-rata kelas eksperimen lebih tinggi yaitu 43 dan kelas kontrol dengan rata-rata 39,14.
\end{abstract}

Kata Kunci: media pembelajaran big book, pembentukan karakter, anak usia dini

\section{DEVELOPING TEACHING MEDIA THROUGH BIG BOOK FOR EARLY CHILDHOOD CHARACTER BUILDING}

\begin{abstract}
This study aims to assist teachers in developing instructional media particularly instructional media in shaping the character of young children in early childhood Bakti Baitussalam Bantul. This study uses research and development $(R \mathcal{E} D)$. The media that has been resulted is the big book media. Data obtained through interview techniques, expert assessment sheets of media and materials. This research subject is child play groups totaling 28 children. Based on the results of the data analysis and discussion, it can be concluded that learning media can be assist teachers in developing instructional media particularly instructional media in shaping the character of young children. The results show that use big book positively effect on the child character building, the experimental class is to gain a higher score is 43 and the control class to obtain a score of 39,14.
\end{abstract}

Keywords: learning media big book, character building, early childhood

How to Cite: Kiromi, I., \& Fauziah, P. (2016). Pengembangan media pembelajaran big book untuk pembentukan karakter anak usia dini. Jurnal Pendidikan dan Pemberdayaan Masyarakat, 3(1), 4859. Retrieved from http://journal.uny.ac.id/index.php/jppm/article/view/5594 


\section{PENDAHULUAN}

Indonesia telah mengalami krisis dalam berbagai bidang, dalam bidang pendidikan, ekonomi, sosial, dan budaya. Hal ini terjadi, seiring berkembangnya zaman dan gaya hidup yang terpengaruh dari luar, sehingga kecintaan dan pengabdian anak bangsa sedikit demi sedikit mulai terkikis, dan akhlak/perilaku generasi muda juga mulai mengkhawatirkan. Seperti data yang didapat oleh Direktorat Jenderal Pemasyarakatan (Ditjenpas Kemenkum) HAM menunjukkan bahwasannya 857 tahanan anak laki-laki dan 17 tahanan anak perempuan, selain itu 2.677 narapidana laki-laki dan 39 narapidana anak perempuan dengan kasusnya masing-masing, kasus narkoba juga menjangkit generasi muda yaitu pelajar dan mahasiswa, menurut Badan Narkotika Nasional (BNN) pada 2014 tercatat 27,32 persen (Data Ditjenpas Kemenkum HAM, April 2015). Hal ini sungguh sangat miris, generasi muda yang seharusnya memberikan kontribusi yang baik bagi kemajuan bangsa akan tetapi mereka habiskan dalam tahanan dengan permasalahan yang mereka lakukan.

Sumber daya manusia juga berpengaruh terhadap krisis yang terjadi. Maka dari itu, peningkatan sumber daya manusia sangat dibutuhkan untuk menciptakan kembali bangsa yang berbudaya dan berkarakter. Suatu bangsa akan maju, jika sumber daya manusia di dalamnya memiliki karakter yang baik. Maka dari itu, untuk meningkatkan kualitas sumber daya manusia yang berkarakter pendidikan sejak dini sangatlah dibutuhkan. Karena, masa anak-anak merupakan masa yang dikenal dengan masa keemasan atau golden age, pada masa itulah pembentukan karakter sangat potensial di berikan pada diri anak-anak. Seperti yang dikatakan oleh Erikson dalam Papalia, Old, \& Feldman (2008, p.370), bahwasannya kesuksesan anak dalam mengatasi sebuah konflik pada masa usia dini, dapat menentukan kesuksesan anak dalam kehidupan sosial pada saat anak beranjak dewasa.

Pendidikan anak usia dini merupakan pendidikan awal pembentukan manusia. Menurut para pakar, sel otak anak sejak usia o sampai 1 tahun pertama sel-sel otak anak atau neuron akan berkembang sangat pesat (Wibowo, 2013, p.2). Menurut Jalongo (2007, p.77) otak pada anak-anak akan berkembang 80 persen sampai usia 8 tahun. Penelitian menunjukkan bahwasannya anak lahir dengan membawa 100 milyar sel otak. Ketika menginjak usia dini, sel-sel tersebut akan terus berkembang sampai beberapa kali lipat dari koneksi awal yaitu sekitar 20.000 koneksi.

Berdasarkan paparan tersebut, telah jelas bahwasanya anak dapat dengan mudah me-nyerap segala sesuatu yang ada di lingkungan sekitar mereka dengan cepat. Maka dari itu, jika anak berada dalam lingkungan yang positif anak akan terbentuk dan terlahir dengan memiliki karakter yang positive pula, akan tetapi jika sebaliknya, maka karkter yang muncul dan terlahir pada diri anak ialah karakter yang negative. Dalam pengenalan dan pembentukan karakter pendidikan merupakan perantara yang dilakukan, pendidikan tidak hanya lingkup sekolah, akan tetapi pendidikan dalam keluarga dan masyarakat juga sangat penting.

Karakter berasal dari bahasa Yunani yang berarti to mark (menandai) dan memfokuskan tentang bagaimana mengaplikasikan nilai-nilai kebaikan dalam suatu tindakan atau tingkah laku. Maka dari itu, seseorang yang berperilaku tidak jujur, kejam, suka mencuri, disebut sebagai orang yang memiliki karakter buruk. Sedangkan orang yang suka berbuat jujur, suka menolong, sopan, bisa dikatakan seseorang yang memiliki karakter yang baik. Jadi, istilah karakter lebih tercermin pada personality (kepribadian) seseorang (Musfiroh, 2008, p.28). Pendidikan karakter merupakan upaya penanaman nilai-nilai karakter kepada anak didik yang meliputi pengetahuan, kesadaran atau kemauan, dan tindakan yang ditujukan untuk melaksanakan nilai-nilai kebaikan dan kebajikan, kepada Tuhan YME, diri sendiri, lingkungan maupun kebangsaan agar menjadi manusia yang berakhlak (Kemendiknas, 2012, p.4).

Pendidikan karakter menurut pendapat Zubaedi, bahwasannya karakter merupakan cara berfikir dan berperilaku yang menjadi ciri khas tiap individu untuk hidup dan bekerja sama, baik dalam lingkungan 
keluarga, masyarakat, bangsa, dan Negara (Fadillah \& Khorida, 2013, p.21).

Dapat disimpulkan, bahwasanya pendidikan karakter merupakan sebuah proses dalam pembentukan anak untuk memiliki pribadi yang baik, memiliki jiwa yang bijaksana dan bertanggung jawab yang dihasilkan dari pembiasaan-pembiasaan pikiran, hati, dan perbuatan yang dilakukan secara berkesinamabungan dalam kehidupan seharihari dan dalam lingkungan sekolah. Nilainilai pendidikan karakter yang dapat ditanamkan pada anak usia dini (o-6 tahun) mencangkup empat aspek, yaitu: (1) aspek spiritual, (2) aspek personal/kepribadian, (3) aspek social, dan (4) aspek lingkungan (Wibowo, 2013, p.66). Untuk membantu penanaman empat aspek nilai karakter kepada anak, pendidik dapat menggunakan berbagai macam metode, salah satunya metode bercerita dengan menggunakan media pembelajaran yang mendukung dalam proses bercerita.

Media berasal dari bahasa latin medius, dan merupakan bentuk jamak dari kata medium yang secara harfiah berarti perantara atau pengantar. Media dalam proses pembelajaran, mampu membantu siswa dalam memahami pembelajaran yang didapat, serta mampu mengangkat minat serta motivasi siswa dalam proses pembelajaran (Latif, Zulkhairina, Zubaidah, \& Afandi, 2013, p.152).

Menurut Asosiasi Teknologi dan Komunikasi Pendidikan (Association of Education and Communication Technology/ $A E C T$ ) membatasi media sebagai segala bentuk dan saluran yang digunakan orang untuk menyalurkan pesan/informasi. Menurut Gagne menyatakan, bahwasannya media adalah berbagai jenis komponen dalam lingkungan siswa yang dapat merangsang siswa untuk belajar (Sadiman \& Raharjo dkk, 2012, p.6).

Dalam pendidikan anak usia dini, media pembelajaran yang digunakan sedikit berbeda dengan media pembelajaran yang digunakan pada jenjang pendidikan yang lebih tinggi. Media pembelajaran di PAUD terdiri atas tiga jenis yaitu (Rolina \& Muhyidin, 2014, p.148): lembar kerja anak (LKA), alat peraga pembelajaran (APP), alat permainan edukatif (APE), Prosedur pengembangan media pembelajaran ini dilakukan melalui tiga tahapan pengembangan. Tiga tahap pengembangan tersebut meliputi desain, prinsip-prinsip media pembelajaran, dan evaluasi (Latif, Zulkhairina, Zubaidah, \& Afandi, 2013, p.157).

Big book merupakan sebuah media yang memiliki karakteristik khusus yang dibesarkan, baik teks maupun gambarnya, serta memiliki karakteristik khusus dalam segi bentuk gambar, warna. Agar dalam proses pembelajaran, di dalamnya terjadi kegiatan membaca bersama (shared reading) antara guru dan murid. Dalam media big book ini, di dalamnya memiliki karakteristik khusus, seperti penuh dengan warna-warni, gambar yang menarik (Gunawan, 2015). Big book termasuk dalam kategori buku bergambar, penggunaan buku bergambar/picture book memberikan manfaat yang besar bagi pembelajaran anak-anak. Gambar merupakan suatu bentuk fungsi semiotic yang dapat dianggap sebagai separuh jalan antara permainan simbolik dan citra mental. Dengan menggunakan buku bergambar, dapat dikatakan anak telah melakukan permainan simbolik, yang memiliki fungsi untuk memberikan kesenangan dan autotelisme dan seperti citra mental dalam upayanya yang meniru kenyataan (Piaget \& Inhelder, 2010, p.72). Buku bergambar merupakan media yang sangat baik untuk membantu mengembangkan sosial emosional anakanak, melatih anak untuk mengekspresikan perasaan yang terdapat pada cerita tersebut. Melalui pembacaan cerita, anak-anak dapat belajar lebih banyak tentang pengetahuan dan ketrampilan emosional dengan mudah.

Menurut Musthafa \& Musbikin (2003, p.5) mendongeng merupakan cerita khayalan atau karangan, akan tetapi jika cerita bisa berbentuk khayalan atau karangan, akan tetapi cerita bisa juga dari kejadian nyata. Keduanya memiliki persamaan, yaitu samasama bertujuan untuk menyampaikan pesan. Metode bercerita sering digunakan oleh guru untuk menyampaikan nilai-nilai yang terkandung dalam cerita tersebut. Metode bercerita, sangat banyak sekali manfaatnya bagi anak-anak, yaitu menambah kosa kata bahasa anak, melatih imajinasi anak. 
Jurnal Pendidikan dan Pemberdayaan Masyarakat, 3 (1), Maret 2016 - 51

Ivonne Hafidlatil Kiromi, Puji Yanti Fauziah

Anak usia dini menurut Nasional Assosiation in Education for Young Children (NAEYC) (Rolina \& Muhyidin, 2014, p.18) adalah anak yang berada pada usia lahir sampai usia 8 tahun. Anak usia dini memiliki potensi genetik dan siap untuk dikembangkan melalui pemberian berbagai rangsangan. Marrison (2012, p.93) berpendapat, pendidikan anak usia dini berada dan dibatasi mulai usia o-8 tahun.

Menurut pengertian anak usia dini di atas, dapat disimpulkan anak usia dini merupakan anak yang berada pada usia o-6 tahun dan ada juga yang mengatakan o-8 tahun. Yang selalu mengalami pertumbuhan dan perkembangan yang sangat luar biasa, sehingga memuculkan berbagai keunikan pada anak. Pada masa inilah, masa yang tepat dalam penanaman nilai-nilai kebaikan, yang nantinya dapat membentuk kepribadian yang baik. Pertumbuhan dan perkembangan memiliki makna yang berbeda. Perkembangan lebih menekankan pada psikis atau kejiwaan seorang anak. Akan tetapi, keduanya memiliki hubungan yang saling berpengaruh antara yang satu dengan lainnya. Pertumbuhan dan perkembangan pada anak usia dini tidak terjadi serta merta dalam satu waktu, tetapi melalui tahapan yang telah di tentukan ukurannya yang membuatnya berjalan dalam proses yang berangsur-angsur atau gradual (Hurlock, 2002, p. 23). Sesuai dengan Permen 58 tahun 2009, yang mengatakan bahwasannya perkembangan anak itu terdiri atas beberapa aspek yaitu perkembangan fisik, kognitif, bahasa, social, dan perkembangan nilai agama dan moral. Seluruh perkembangan yang terjadi pada anak tersebut, saling mempengaruhi satu dengan lainnya, tidak satupun yang berdiri sendiri.

Menurut penjelasan dari beberapa ahli tersebut dapat disimpulkan bahwa, perkembangan merupakan perubahan yang dialami untuk menuju tingkat kedewasaan atau kematangan yang berlangsung secara sistematis. Perkembangan pada anak seharusnya dilakukan secara menyeluruh (holistik) sehingga anak mampu berkembang secara maksimal, sehingga anak memiliki kepribadian yang baik, sehat dan imbang.

\section{METODE}

\section{Jenis Penelitian}

Penelitian ini menggunakan metode penelitian dan pengembangan. Penelitian dan pengembangan (R\&D) bisa didefinisikan sebagai metode penelitian yang secara sengaja, sistematis, bertujuan/diarahkan untuk mencaritemukan, merumuskan, memperbaiki, mengembangkan, menghasilkan, menguji keefektifan produk, model, metode/strategi/cara, jasa, posedur tertentu yang lebih unggul, baru, efektif, efisien, produktif, dan bermakna (Putra, 2013, p.67). Dalam rangka menghasilkan produk media big book sebagai media pembelajaran yang mampu membantu anak-anak pada tahap perkembangan moral, model pengembangan yang akan digunakan dalam penelitian ini adalah model penelitian dan pengembangan pendidikan (Educational Research $\mathcal{E}$ Development). Menurut Borg \& Gall (1983) bahwasanya penelitian dan pengembangan terdiri atas 10 tahap, namun dalam (Tim Puslitjaknov 2008, p.11) prosedur penelitian pengembangan menurut Borg \& Gall dapat dilakukan dengan lebih sederhana, yaitu hanya melakukan 5 langkah utama, yaitu: (1) Melakukan analisis produk yang akan dikembangkan, (2) Mengembangkan produk awal, (3) Validasi dan revisi, (4) Uji coba lapangan skala kecil dan revisi produk, (5) Uji coba lapangan skala besar dan produk akhir.

\section{Desain Uji Coba}

Uji coba produk merupakan tahap pengembangan yang dilakukan dengan dua tahap yaitu uji coba 1 (uji coba terbatas) dan uji coba 2 (uji coba lapangan). Uji coba terbatas menggunakan desain one shot Case Study karena penilaian hanya menggunakan nilai akhir hasil belajar (posttest) tanpa menggunakan pretest (Sugiyono, 2007, p.110). Uji coba lapangan menggunakan metode quasi eksperimen dengan rancangan control-group pretest dan posttest design. Kelas kontrol kelas B dan kelas eksperimen kelas $\mathrm{C}$.

\section{Subjek Uji Coba}

Subjek uji coba dalam penelitian pengembangan yang dilakukan ini sebanyak 28 


\section{Jurnal Pendidikan dan Pemberdayaan Masyarakat, 3 (1), Maret 2016 - 52}

Ivonne Hafidlatil Kiromi, Puji Yanti Fauziah

anak di PAUD Bakti Baitussalam Yogyakarta Semester 2 Tahun Ajaran 2014/2015. Subjek uji lapangan pendahuluan (uji coba kelompok kecil) berjumlah 6 anak usia 3-4 tahun diambil secara acak yang dilakukan oleh pendidik di Baitussalam. Subjek uji coba II (uji coba kelompok besar) adalah kelas KB B dan KB C.

\section{Jenis Data}

Data yang diperoleh dari penelitian ini merupakan data primer. Data ini merupakan data yang berkaitan dengan validasi serta tanggapan dari para ahli media dan materi, dan guru tentang media pembelajaran big book yang di kembangkan oleh peneliti. Selain itu, data keterlaksanaan dari media big book dalam proses pembelajaran serta data efektivitas big book dalam menanamkan karakter setelah mengikuti aktivitas pembelajaran.

\section{Teknik dan Instrumen Pengumpulan Data}

Instrumen pengumpulan data dalam penelitian pengembangan ini adalah model hipotetik dari media pembelajaran big book dan pedoman observasi. Model hipotetik merupakan rancangan model yang akan diujicobakan kelayakannya di lapangan. Sedangkan pedoman observasi adalah alat yang digunakan untuk acuan pengamatan. Pedoman observasi pada penelitian ini menggunakan rating scale.

Observasi dapat dilakukan secara partisipatif ataupun nonpartisipatif (Sukmadinata, 2012, p.220). Dalam penelitian ini, peneliti menggunakan nonpartisipatif (nonparticipatory observation) yang mana peneliti tidak ikut serta dalam kegiatan, peneliti hanya berperan mengamati kegiatan yang terjadi di lapangan, tidak ikut dalam kegiatan.

\section{Teknik Analisis Data}

Untuk mengetahui kualitas media pembelajaran yang telah dikembangkan baik dari aspek materi dan dari aspek media, maka data yang masih berupa skor, diubah menjadi data kualitatif (data interval) dengan skala lima. Adapun acuan pengubahan skor menjadi skala lima tersebut menurut
Sukardjo, dkk (2010, p.10o) ditunjukkan pada Tabel 1.

Tabel 1. Konversi Skor Aktual Menjadi Nilai Skala 5 (Sukardjo, 2010, p.10o)

\begin{tabular}{|c|c|c|}
\hline $\begin{array}{c}\text { Data } \\
\text { Kuantitatif }\end{array}$ & Rentang & $\begin{array}{c}\text { Data } \\
\text { Kualitatif } \\
\end{array}$ \\
\hline 5 & $\mathrm{X}>\mathrm{Xi}+1,8$ o Sbi & Sangat baik \\
\hline 4 & $\begin{array}{c}\mathrm{Xi}+\mathrm{o}, 60 \\
\mathrm{Sbi}<\mathrm{X} \leq \mathrm{Xi}+1,80 \mathrm{Sbi}\end{array}$ & Baik \\
\hline 3 & $\begin{array}{c}\mathrm{Xi}-\mathrm{o}, 60 \\
\mathrm{Sbi}<\mathrm{X} \leq \mathrm{Xi}+\mathrm{o}, 60 \text { Sbi }\end{array}$ & Cukup \\
\hline 2 & $\begin{array}{c}\mathrm{Xi}-1,8 \text { o } \mathrm{Sbi}<\mathrm{X} \leq \mathrm{Xi}- \\
\text { o,6o Sbi }\end{array}$ & Kurang \\
\hline 1 & $\mathrm{X} \leq \mathrm{Xi}-1,80$ Sbi & $\begin{array}{l}\text { Sangat } \\
\text { kurang }\end{array}$ \\
\hline
\end{tabular}

Data yang diperoleh dianalisis dengan menggunakan statistik deskriptif kualitatif. Analisis ini dimaksudkan untuk menggambarkan karakteristik data pada masing-masing variabel. Dengan ini, diharapkan dapat mempermudah dalam memahami data untuk proses analisis selanjutnya. Hasil analisis data digunakan sebagai dasar untuk merevisi produk media yang dikembangkan. Uji hipotesis menggunakan SPSS (Statistical Package for The Social Sciencs) 16.o for windows yaitu paket uji statistik untuk ilmu sosial. Uji $t$ digunakan untuk mengetahui signifikasi pengaruh variabel bebas yaitu Media pembelajaran big book (X) terhadap pembentukan karakter anak (Y) sehingga bisa diketahui apakah dugaan yang sudah ada dapat diterima atau ditolak.

\section{HASIL DAN PEMBAHASAN}

\section{Penelitian Pendahuluan}

Analisis kebutuhan dilakukan dengan melakukan kegiatan wawancara dengan 4 guru dan kepala sekolah, hasil dari wawancara yang berkaitan dengan media pembelajaran yang selama ini dilakukan serta diinginkan oleh pendidik, menunjukkan bahwa guru sering mengalami kesulitan dalam menyampaikan materi khususnya dalam menyampaikan dan pengenalan nilai karakter pada anak. Kesulitan yang dialami berkaitan dengan respon anak yang kurang termotivasi dalam mendengarkan materi yang diberikan oleh guru, karena kurangnya media pembelajaran khususnya dalam alat peraga edukasi. 


\section{Jurnal Pendidikan dan Pemberdayaan Masyarakat, 3 (1), Maret 2016 - 53 \\ Ivonne Hafidlatil Kiromi, Puji Yanti Fauziah}

Sebab lain, kurang tersedianya media buku cerita untuk anak-anak, sehingga guru kesulitan dalam bercerita dan dalam pengenalan nilai karakter pada anak. Untuk itu, pembelajaran yang sering dilakukan oleh guru dengan cara berceramah, dan mengerjakan majalah sesuai dengan tema pembelajaran pada saat itu. Setelah melakukan analisis lapangan di lokasi penelitian tentang kebutuhan pihak sekolah dan kebutuhan guru saat mengajar, peneliti dapat mengambil sebuah kesimpulan bahwasanya dalam proses pembelajaran guru mengalami kesulitan, karena kurangnya alat peraga dan buku-buku cerita, khususnya cerita tentang kisah-kisah tauladan dan yang berkaitan dengan nilai-nilai karakter.

Akibat dari terbatasan media pembelajaran yang digunakan, khususnya dalam hal buku cerita sehingga guru jarang membacakan cerita keteladanan kepada anak-anak. Selain itu, dalam proses pembelajaran dalam menjelaskan suatu materi yang sesuai tema, guru tidak menggunakan alat peraga yang sesuai dengan tema, sehingga anak hanya membayangkan apa yang di jelaskan oleh guru, dan anak cenderung bosan, mengantuk dan ramai sendiri dengan temantemannya.

\section{Penyusunan Prototipe Produk}

Setelah menelaah hasil analisis kebutuhan pendidik, langkah selanjutnya adalah menyusun prototype produk pengembangan media pembelajaran. Prosedur pengembangan media pembelajaran big book, adalah sebagai berikut: menentukan nilai karakter yang akan diangkat dalam cerita, nilai karakter tersebut adalah kejujuran, disiplin, dan menjaga lingkungan, pelaksanaan pengembangan, menyusun media pembelajaran big book untuk pembentukan karakter anak, review dan uji coba produk yang terdiri atas review ahli media dan materi, revisi, dan uji coba skala kecil dan besar, dan tahap terakhir yaitu final media pembelajaran big book untuk pembentukan karakter anak.

\section{Data Uji Coba Hasil Pengembangan}

\section{Data Ahli Materi}

Dalam memvalidasi suatu produk media pembelajaran yang dikembangkan, ahli materi yang di gunakan yaitu dosen UNY, yaitu Yulia Ayriza, M.Si, Ph D. Secara terpisah turut memberikan masukan dan saran lisan Ibu Ninik pendidik di PAUD Bakti Baitussalam, yang sekaligus sebagai tempat peneliti melakukan penelitian. Uji ahli materi dilakukan melalui diskusi, angket, wawancara dengan hasil sebagai berikut, ahli materi terdiri atas 1 dosen UNY, yaitu dosen psikologi perkembangan anak.

Data yang terkumpul melalui angket menunjukkan bahwa, dari aspek isi materi bahwa materi sudah sesuai dengan indikator karakter anak yang telah ditentukan, sedangkan untuk dari aspek bahasa bahwa bahasa yang digunakan masih perlu perbaikan, yaitu disesuaikan dengan ejaan bahasa yang di sempurnakan (EYD), agar cerita yang diterima oleh anak dapat diterima dengan mudah. Secara keseluruhan penilaian dari aspek materi dan bahasa mencapai 122 dengan rata-rata akhir 4,06 yang jika dikonversikan dari kuantitatif menjadi kualitatif termasuk dalam kategori baik.

Selain angket, juga dilakukan wawancara mengenai produk media pembelajaran big book, baik tentang kebenaran konsep, kedalaman cerita, dan tanggapan-tanggapan serta komentar umum dalam rangka perbaikan atau revisi sebelum ke tahap berikutnya. Hasil wawancara dengan ahli materi bahwa, produk media pembeljaran big book perlu ditambah, karena jika produk yang dibuat hanya satu macam, maka hasil yang didapat kurang maksimal, dan anak akan cepat bosan apabila produk yang digunakan hanya satu macam, judul pada buku ke tiga tentang "aku bisa melakukan sendiri" tidak sesuai dengan karakter yang telah diangkat yaitu disiplin, judul tersebut mengarahkan kepada anak untuk berbuat mandiri. Apabila karakter yang diangkat tentang disiplin maka judul yang diangkat bisa menjadi "mentaati peraturan". Dalam naskah cerita, masih terdapat kalimat yang tidak baku, masih terdapat kalimat yang sangat panjang, sehingga perlu disederhankan kembali. 
Kemudian dalam indikator penilaian karakter, masih terdapat dua kategori penilaian dalam satu kalimat, hal itu dapat mempersulit pada saat melakukan penilaian, sehingga dua penilaian dalam satu kalimat tersebut dapat menjadi penilaian pada masingmasing indikator, dan yang terakhir masih terdapat indikator penilaian yang sangat rumit untuk anak-anak, maka dari itu perlu diganti dengan yang lain yang sesuai dengan tingakat perkembangan anak dan kegiatan sehari-hari anak disekolah.

Simpulan hasil dari ahli materi, produk media pembelajaran big book layak untuk diuji cobakan dengan revisi. Hasil dikaji oleh penelliti, sebagai dasar perbaikan produk terutama dari segi tampilan produk serta penyajian produk.

\section{Data Ahli Media}

Validasi ahli media dilakukan oleh dosen FIP yang juga dosen Program Pascasarjana Universitas Negeri Yogyakarta yaitu, Dr. Sujarwo. Evaluasi ahli media pembelajaran dimaksudkan untuk memperoleh masukan tentang kualitas tampilan media, dan aspek pembelajaran. Adapun hasil evaluasi ahli media pebelajaran yaitu berupa skor penilaian terhadap beberapa aspek yang mencangkup aspek tampilan, dan aspek pembelajaran. Penilaian yang dilakukan oleh ahli media mendapatkan skor 146 apabila dirata-ratakan mendapatkan hasil 4,05 dan jika dikonversikan dari kuantitatif menjadi kualitatif termasuk dalam kategori baik.

Selain melakukan penilaian melalui angket, ahli media juga memberikan masukan tentang produk media pembelajaran big book yaitu dari aspek warna yang terdapat pada media, perpaduan warna yang terdapat pada big book menggunakan warna yang kontras dan cerah supaya dapat menarik perhatian anak, penggunaan produk media big book lebih diperjelas dengan langkahlangkah penggunaan.

Kemudian dalam naskah cerita, sebaiknya jika menggunakan karakter binatang menggunakan kelompok yang sejenis, misalnya kupu-kupu merah, kupu-kupu biru dan lebah, tidak menggunakan si biru, si merah dan lebah. Kemudian dalam font dan huruf penulisan dalam naskah lebih diperbesar yaitu menggunakan font 16-18 agar dapat mempermudah guru dalam memahami naskah cerita, format penulisan untuk lebih dirapikan kembali dan didukung hiasan di setiap halamannya, kemudian alur dalam cerita dibuat lebih sistematis lagi. Setelah memberikan saran terhadap produk pengembangan media pembelajaran big book, tahap akhir ahli media memberikan kesimpulan bahwasanya media pembelajaran big book layak untuk diujicobakan dengan revisi. Hasil review dari ahli media dikaji kembali oleh peneliti, sebagai dasar untuk revisi produk terutama dari aspek tampilan.

\section{Data Uji Coba Kelompok Kecil}

Media pembelajaran yang telah divalidasi oleh ahli materi dan ahli media serta telah direvisi berdasarkan catatan dari para ahli tersebut, kemudian diujicobakan pada lapangan terbatas. Uji coba lapangan terbatas menggunakan sampel anak-anak di Kelompok Bermain Baitussalam sebanyak 6 orang anak dengan rentang usia 3-4 tahun. Penggunaan media big book itu sendiri, digunakan setiap kali dalam proses penelitian kelas kecil.

Peneliti menjelaskan tentang penggunaan media big book kepada pendidik, bahwasannya penggunaan media tersebut anak juga ikut dilibatkan agar anak dapat meraba untuk melatih motorik halus anak, dengan cara memegang dan meraba, selain itu tujuan penggunaan dari media tersebut, mengajak untuk mengenal warna-warna yang ada dalam media tersebut. Dan mengajak anak untuk bercerita dengan imajinasinya masing-masing. Dengan melibatkan anak dalam kegiatan pembelajaran, diharapkan apa yang didapat oleh anak dapat melekat dalam benak anak, dan anak akan selalu ingat tentang cerita yang ada dalam media tersebut.

Hasil yang diperoleh dapat dilihat bahwa, setiap indikator pada nilai karakter memiliki nilai yang sedang, hanya pada indikator dalam menjaga lingkungan memiliki nilai yang tinggi. Secara keseluruhan penggunaan media big book dalam pembentukan karakter anak mencapai 3,36 dengan kategori tinggi.

Hasil uji coba kelompok kecil ini dikaji kembali oleh peneliti, sebagai dasar revisi 


\section{Jurnal Pendidikan dan Pemberdayaan Masyarakat, 3 (1), Maret 2016 - 55}

Ivonne Hafidlatil Kiromi, Puji Yanti Fauziah

produk untuk uji coba kelompok besar. Dalam uji coba kelompok kecil ini, juga dilakukan diskusi dan observasi, hasilnya menurut guru, big book yang menggunakan karakter binatang kurang tepat untu anak usia 3-4 tahun, dikarenakan karakter tersebut memiliki tingkatan yang tinggi, anakanak lebih suka apabila karakter yang diangkat manusia, yang mana dalam bercerita anak dapat dimasukkan pada saat proses bercerita untuk menjadi karakter orang yang terdapat dalam cerita.

\section{Data Uji Coba Kelas Besar}

Uji coba luas media pembelajaran big book dilakukan setelah uji coba terbatas. Terdapat dua kelas yang digunakan yaitru kelas KB B dan kelas KB C. Kedua kelas tersebut dipilih karena usia yang sama yaitu 3-4 tahun, yang akan menginjak ke tingkat taman kanak-kanak. Sebelum menggunakan media pembelajaran big book peneliti melakukan pretes terlebih dahulu, yaitu dengan melakukan pengamatan sebelum menerapkan media pembelajaran big book.

Pengamatan tersebut dilakukan pada dua kelas yang telah dipilih, yaitu kelas B sebagai kelas kontrol dan kelas $C$ sebagai kelas eksperimen. Pada penilaian yang menggunakan dua kelas ini, peneliti meminta bantuan kepada salah satu guru kelas pada kelas B sebagai observer. Hasil yang didapat pada pretest kelas kontrol adalah 31,64 berkategori "baik". Sedangkan pada kelas eksperimen diperoleh nilai rata-rata 32,28 berkategori "baik". Setelah melakukan penilaian pretest pada kelas kontrol dan eksperimen, peneliti melakukan posttest pada kelas kontrol dan kelas eksperimen. Penilaian ini dilakukan setelah menggunakan media pembelajaran big book untuk kelas eksperimen dan pada kelas kontrol guru bercerita menggunakan buku cerita yang telah dipersiapkan oleh peneliti. Hasil yang didapatkan oleh peneliti pada posttes kelas kontrol adalah 39,14 dengan kategori "sangat baik", dan kelas eksperimen 43 dengan kategori "sangat baik".

Selain menilai hasil post tes penggunaan media, juga dilakukan penilaian hasil uji beda ketercapaian setiap nilai karakter yang diberikan, hasil uji beda yang diperoleh pada nilai karakter kejujuran berdasarkan hasil perhitungan independent sample t-test pada gain standar ketercapaian karakter anak dapat dilihat bahwa $F=0,200$ dengan tingkat signifikansi o,670 lebih besar dari o,050. Hal tersebut menunjukkan bahwa sesungguhnya varians gain standar ketercapaian karakter anak antara kelas kontrol dan eksperimen adalah sama yaitu -2,777. Dalam uji ini digunakan kedua varians sama (equal varians assumed). Pada uji $t$ gain standar untuk varians sama yaitu $-2,777$ dengan tingkat signifikan 0,032. Karena nilai tingkat signifikan lebih kecil dari o,05 maka $\mathrm{H}_{0}$ ditolak. Berdasarkan hal tersebut maka dapat disimpulkan bahwa terdapat perbedaan signifikan terhadap ketercapaian pembentukan karakter kejujuran anak antara kelas yang menggunakan media pembelajaran konvensional dengan media pembelajaran hasil pengembangan.

Hasil uji beda untuk nilai karakter disiplin, berdasarkan hasil perhitungan independent sample t-test pada gain standar ketercapaian karakter anak dapat dilihat bahwa nilai $F=0,725$ dengan tingkat signifikansi 0,419 lebih besar dari 0,05. Hal tersebut menunjukkan bahwa sesungguhnya varians gain standar ketercapaian karakter anak antara kelas control dan kelas eksperimen adalah sama yaitu $-4,575$. Dalam uji ini digunakan kedua varians sama (equal varians assumed). $t$ gain standar menunjukkan memiliki varians yang sama yaitu -4,575 dengan tingkat signifikansi o,ooz. Karena nila tingkat signifikansi lebih kecil dari o,o5 maka $\mathrm{H}_{0}$ ditolak. Berdasarkan hal tersebut maka dapat disimpulkan bahwa ada perbedaan signifikan terhadap ketercapaian pembentukan karakter disiplin antara kelas yang menggunakan media pembeljaran konvensional dan media pembelajaran hasil pengembangan.

Dan hasil uji beda untuk nilai karakter menjaga lingkungan berdasarkan hasil perhitungan independent sample t-test pada gain standar ketercapaian karakter anak dapat dilihat bahwa nilai $F=0,157$ dengan tingkat signifikansi 0,712 lebih besar dari o,05. Hal tersebut menunjukkan bahwa sesungguhnya varians gain standar keter-capaian karakter anak antara kelas control dan eksperimen 
Jurnal Pendidikan dan Pemberdayaan Masyarakat, 3 (1), Maret 2016 - 56

Ivonne Hafidlatil Kiromi, Puji Yanti Fauziah

adalah sama yaitu -o,868. Dalam uji ini digunakan kedua varians sama (equal varians assumed). Pada hasil penghitungan menunjukkan bahwa nilai $t$ gain standar untuk varians sama yaitu -0,868 dengan tingkat signifikansi o,434. Karena nilai signifikansi lebih besar dari o,o5 maka $\mathrm{H}_{1}$ ditolak. Berdasarkan hasil tersebut maka dapat disimpulkan bahwa tidak ada perbedaan signifikan terhadap ketercapaian pembentukan karakter menjaga lingkungan antara kelas yang menggunakan media pembelajaran yang konvensional dengan kelas yang menggunakan media pembelajaran hasil pengembangan.

Setelah dilakukan perhitungan terhadap karakter kejujuran, disiplin, dan menjaga lingkungan dapat disimpulkan bahwa media pembelajaran big book memiliki pengaruh yang signifikan terhadap pembentukan karakter anak. Hal itu terjadi karena dalam proses pembelajaran anak dilibatkan langsung dalam bercerita dan dilibatkan untuk mengaplikasikan langsung di lapangan untuk melihat kebersihan lingkungan sekolah dan kerapian kelas di akhir pembelajaran.

Setelah melakukan uji coba produk media pembelajaran big book, peneliti memberikan angket kepada pendidik. Penilaian yang dilakukan guru setelah menggunakan media big book mendapatkan hasil yang sangat tinggi yaitu 8,57 . Hal ini, termasuk dalam kategori layak digunakan dalam proses pembelajaran, khususnya pada pembelajaran pembentukan karakter anak.

\section{Revisi Produk}

Revisi dilakukan berdasarkan saran dan masukan dari para ahli materi dan ahli media. Dari aspek pembelajaran dapat dilihat dari segi bahasa yang digunakan dalam naskah cerita, dilakukan revisi dengan lebih disederhanakan, menggunakan bahasa yang baku sesuai dengan ejaan yang disempurnakan (EYD) sesuai dengan tingkat pemahaman bahasa anak usia dini. Hal ini bertujuan, agar cerita yang disampaikan oleh guru dapat diterima dengan mudah oleh anakanak. Demikian pula dengan naskah cerita yang terlalu panjang disederhanakan agar anak-anak tidak bosan dan mengantuk.
Untuk semakin menambah pemahaman anak tentang nilai-nilai karakter, pada awal mulanya big book hanya menghasilkan satu buku, dibuat lebih banyak oleh peneliti, yaitu berjumlah 3 buku, sesuai dengan saran dari ahli materi untuk menambah media big book yang telah dibuat. Dengan bertambahnya media pembelajaran big book yang berjumlah 3 buku, diharapkan anak akan suka dan tidak bosan.

\section{Kajian Produk Akhir}

Proses pengembangan tersebut memakan waktu kurang lebih 4 bulan. Hasil akhirnya adalah produk media pembelajaran big book untuk pembentukan karakter anak yang berjumlah tiga buku. Berdasarkan hasil observasi anak dan evaluasi yang dilakukan dengan penilaian media oleh guru pada uji coba kelas besar diketahui bahwa media yang dikembangkan oleh peneliti dapat diterapkan untuk membantu pembentukan karakter anak, hal ini dapat dilihat dari penilaian indikator-indikator yang berhubungan dengan sikap anak disekolah. Dalam observasi anak kelompok kelas besar secara keseluruhan memperoleh rata-rata 4,067 dan data hasil penilaian dari guru kelas memperoleh rata-rata 8,57 , yang bila dikonversikan kepada data kualitatif, maka akan disimpulkan bahwa hasil observasi anak dan penilaian dari guru adalah "sangat baik".

Berdasarkan hasil pengembangan tersebut dapat dinyatakan bahwa media pembelajaran big book efektif dalam pembentukan karakter anak, karena media big book merupakan media yang terdiri atas bermacam-macam gambar dan warna, yang dapat memberikan manfaat yang besar bagi anak, karena dengan menggunakan media bergambar anak sudah belajar secara simbolik yang memiliki fungsi untuk memberikan kesenangan dan autotelisme dan citra mental yang dapat meniru perilaku di lingkungan anak.

Media big book yang dihasilkan dalam penelitian ini memiliki beberapa karakteristik dan keunggulan, yaitu media big book yang memiliki karakteristik ukuran media yang besar, bentuk gambar yang menarik serta warna yang mencolok yang mampu menarik perhatian anak-anak seperti yang 


\section{Jurnal Pendidikan dan Pemberdayaan Masyarakat, 3 (1), Maret 2016 - 57}

Ivonne Hafidlatil Kiromi, Puji Yanti Fauziah

diungkapkan oleh Gunawan (2015). Untuk mengetahui daya tarik media big book bagi anak, dapat dilihat pada saat anak asik bermain dengan media tersebut bersama teman-teman, dan hasil wawancara dengan guru kelas. Aspek daya tarik lebih disebabkan dari aspek tampilan maupun dari gambar yang ada dalam media tersebut. Interaktivitas antara anak dengan media tersebut dibangun dari adanya bercerita bersama dengan teman-temannya. Karena proses bercerita yang dilakukan anak-anak dengan temannya merupakan kegiatan yang dapat mengembangkan daya imajinasi anakanak, hal ini sesuai dengan yang diungkapkan Musfiroh (2008, p.78) bahwa manfaat dari metode bercerita dapat mengembangkan bahasa pada anak, serta mengasah imajinasi pada anak.

Cerita yang terdapat dalam media big book tersebut dikemas sangat menarik sesuai dengan indikator nilai-nilai karakter yang diangkat oleh peneliti, yaitu yang berisikan tentang sikap jujur, disiplin dan menjaga lingkungan sekitar. Dengan demikian produk media pembelajaran big book ini sesuai untuk membantu dalam pembentukan karakter anak.

Nilai-nilai yang termuat dalam media ini antara lain; Nilai Kejujuran, pada cerita kupu-kupu dan lebah yang bersahabat, yang selalu berbagi makanan, minuman dan selalu berkata jujur, akibat kupu-kupu berbohong kepada sahabatnya dia mendapatkan musibah, dan akhirnya meminta maaf kepada kedua temannya. Nilai Disiplin, menceritakan tentang seorang anak yang asik bermain, dan lupa membereskan mainannya pada saat ingin beranjak tidur. Ibu membantu sang anak untuk membereskan mainannya kembali. Menjaga Lingkungan Sekitar, menceritakan kakak dan adik yang sedang asik berjalan-jalan ditaman, melihat sampah berserakan. Sehingga kedua saudara tersebut memungut sampah dan membuang sampah tersebut pada tempatnya.

Pada penggunaan media big book ini dengan menggunakan metode bercerita, bertujuan untuk melatih anak dalam mengembangkan imajinasinya. Anak juga dilatih untuk mengolah perasaan dan empati ter- hadap kejadian yang dialami oleh pelaku dalam cerita tersebut.

\section{Keterbatasan Penelitian}

Penelitian yang dilakukan ini hanya terbatas pada lingkup masalah yang sangat terbatas, mengingat permasalahan yang terkait dengan minimnya penggunaan media pembelajaran dalam proses pembelajaran, khususnya dalam pengenalan nilai karakter dan pembentukan karakter pada anak. Permasalahan tersebut meliputi guru, siswa, media, dan bahan ajar, sarana, model pembelajaran dan sebagainya. Dari berbagai masalah tersebut, peneliti ini hanya dibatasi pada masalah media. masalah media ini terbatas pada media pembelajaran dengan berbentuk big book untuk membantu pembentukan karakter anak. Produk media big book yang dikembangkan ini, dibatasi penggunaannya hanya untuk anak kelompok bermain usia 3-4 tahun. Sekolah yang digunakan sebagai sumber terbatas pada PAUD Bakti Baitussalam, Imogiri Timur-Banguntapan Bantul. Hal itu dilakukan mengingat keterbatasan dan kemampuan peneliti.

\section{PENUTUP}

\section{Simpulan}

Pengembangan media pembelajaran big book dilaksanakan melalui lima tahapan yaitu: analisis kebutuhan, mengembangkan produk awal, validasi para ahli dan revisi, uji coba lapangan skala kecil dan revisi, dan uji coba lapangan skala besar dan produk akhir. Pada proses penilaian yang dilakukan oleh para ahli, yaitu ahli materi menghasilkan rerata skor 4,06 dengan kategori baik, dan ahli media dengan mendapatkan rerata skor 4,05 dengan kategori baik. Dengan kesimpulan media pembelajaran big book layak untuk diujicobakan dengan revisi sesuai saran.

Terdapat perbedaan skor antara kelas kontrol dan eksperimen, kelas eksperimen memperoleh rerata skor yaitu 43 dengan kategori sangat baik, dan rerata perolehan untuk kelas kontrol adalah 39,14 dengan kategori sangat baik. Dari rerata perolehan yang didapat, kelas eksperiemen memperoleh hasil yang lebih baik dari kelas kontrol. 


\section{Jurnal Pendidikan dan Pemberdayaan Masyarakat, 3 (1), Maret 2016 - 58}

Ivonne Hafidlatil Kiromi, Puji Yanti Fauziah

Dengan perolehan tersebut, dapat disimpulkan bahwa media pembelajaran big book memiliki pengaruh yang signifikan terhadap pembentukan karakter anak.

\section{Saran}

\section{Bagi Pendidik PAUD}

Hasil pengembangan ini dapat digunakan sebagai salah satu alternatif media pembelajaran dalam pengenalan nilai-nilai karakter serta mengenal warna, bentuk dan angka. Produk ini, dapat memacu semangat anak untuk ikut terlibat dalam pembelajaran, khususnya pada saat guru bercerita.

Bagi Peneliti Mendatang

Diharapkan peneliti yang akan datang dapat melakukan penelitian mengenai pelatihan dengan pendidik PAUD dalam pengembangan media pembelajaran yang menggunakan media berbahan barang bekas.

\section{Diseminasi dan Pengembangan Produk}

Diseminasi sampai saat ini dapat dilakukan terbatas dilingkungan sekolah, karena masih merupakan hasil dari pengembangan yang memerlukan penyempurnaan lebih lanjut. Dan pengembangan ini tidak hanya terbatas pada media pembelajaran dalam lingkup pengenalan nilai-nilai karakter saja, akan tetapi juga keseluruhan yang dibutuhkan bagi perkembangan anak tiap-tiap usia. Agar anak-anak terbantu dalam meningkatkan setiap aspek perkembangannya sesuai dengan usia masing-masing.

\section{DAFTAR PUSTAKA}

Borg, WR. \& Gall, MD. (1983). Educational research: an introduction. (Rev.ed). New York: Longman

Ditjenpas Kemenkum HAM (2 Mei 2015). Fokus bangun karakter. Jawa Pos. hlm.7

Fadillah, M \& Khorida, L.M. (2013). Pendidikan karakter anak usia dini. Jogjakarta: Arruz Media

Gunawan, D. (2015). Sekali lagi tentang big book. Diambil pada tanggal 5 April 2015, http://www.kompasiana.com/dedygun awanhutajulu

Hurlock, EB. (2002). Perkembangan anak. Jilid 1. Jakarta: Erlangga

Jalongo, M R. (2007). Early childhood language arts. New York: Person Education, Inc.

Kemendiknas. (2012). Pedoman pendidikan karakter pada anak usia dini. Jakarta

Latif, M., Zulkhairina., Zubaidah, R., \& Afandi, M. (2013). Orientasi baru pendidikan anak usia dini: Teori dan aplikasi. Jakarta: Prenada Media.

Musthafa, A \& Musbikin, I. (2003). Sepasang burung dan Nabi Sulaiman. Yogyakarta: Mitra Pustaka.

Musfiroh, T. (2008). Character building. Yogyakarta: Tiara Wacana.

Morrison, GS. (2012). Dasar-dasar pendidikan anak usia dini (PAUD). Jakarta: Indeks.

Putra, Nusa. (2013). Research $\mathcal{E}$ development penelitian dan pengembangan: Suatu pengantar. Jakarta:Rajawali Pers.

Piaget, J. \& Inhelder, B. (2010). Psikologi anak, the psychology of the child. Yogyakarta: Pustaka Pelajar.

Papalia, DE., Old, SW., \& Feldman, RD. (2008). Human development (psikologi perkembangan). Jakarta: Kencana.

Rolina, Nelva \& Muhyidin. (2014). Ensikopledia pendidikan anak usia dini, metode $\mathcal{E}$ media pembelajaran. Yogyakarta: Insan Madani.

Sugiyono. (2007). Penelitian kualitatif, kuantitatif, dan RED. Bandung: Alfabeta.

Sukmadinata, N.S. (2012). Metode penelitian pendidikan. Bandung: PT. Remaja Rosdakarya

Sukardjo, dkk. (2010). Desain pembelajaran: evaluasi pembelajaran. Handout perkuliahan: Yogyakarta, Program Pascasarjana Universitas Negeri Yogyakarta.

Sadiman, A.S. \& Rahardjo R., dkk. (2012). Media pendidikan. Jakarta: Raja Grasindo Persada.

Tim Puslitjaknov. (2008). Metode penelitian pengembangan. Badan Penelitian dan 
Jurnal Pendidikan dan Pemberdayaan Masyarakat, 3 (1), Maret 2016 - 59 Ivonne Hafidlatil Kiromi, Puji Yanti Fauziah

Pengembangan

Pendidikan Nasional.
Departemen Wibowo, Agus. (2013). Pendidikan karakter usia dini. Yogyakarta: Pustaka Pelajar. 